\title{
PHYSICAL ACTIVITY TO IMPROVE THE PHYSIOLOGICAL INDEX OF CARDIOVASCULAR EFFECT
}

\author{
A ATIVIDADE FISICA NO REESTABELECIMENTO DO ÍNDICE FISIOLÓGICO DEEFEITO CARDIOVASCULAR
}

\section{LA ACTIVIDAD FÍSICA EM EL RESTABLECIMIENTO DEL ÍNDICE FISIOLÓGICODEEFECTO CARDIOVASCULAR}

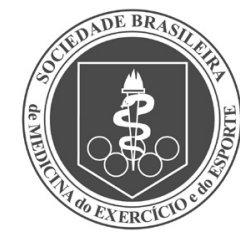

Original Article ARTIGO ORIGINAL Artículo Original

\section{Mei Qin' (1D}

(Physical Education Professional)

Cunshan Peng ${ }^{2}$ (D)

(Physical Education Professional)

Qingke Wang ${ }^{1}$ (ID)

(Physical Education Professional)

1. Department of PE, Xuzhou Medical School, Jiangsu Union Technical Institute, Xuzhou, Jiangsu 221116, China.

2. Department of $P E$, Jiuzhou Polytechnic Institute, Xuzhou, Jiangsu 221116, China.

\section{Correspondence}

Mei Qin

Xuzhou, Jiangsu China, 221116. qmhappy1227@163.com

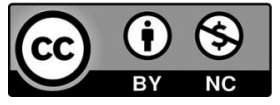

\begin{abstract}
Introduction: Physical exercise can enhance the body's ability to adapt to the external environment and improve the contractility of the heart. At the same time, it can help improve blood circulation and increase lung capacity. Objective: This article explores the critical role of sports in the prevention of cardiovascular diseases. Methods: This article conducts tests on related physiological indicators such as hemodynamic rheology for students who regularly participate in physical exercise and those who do not participate in physical exercise. Results: Students who exercise regularly and those who do not exercise mobilize faster cardiovascular function at the beginning of work. This shows good adaptability to sports. Conclusion: The use of fitness exercise prescription by students who exercise comprehensively has the most pronounced effect on improving vascular function. Level of evidence Il; Therapeutic studies - investigation of treatment results.

Keywords: Sports; Blood pressure monitor; Heart rate; Cardiovascular fitness.

\section{RESUMO}

Introdução: O exercício físico pode aumentar a capacidade do corpo de se adaptar ao meio ambiente e melhorar a contratilidade do coração. Ao mesmo tempo, pode reestabelecer a circulação sanguínea e aumentar a capacidade pulmonar. Objetivo: Este artigo explora o papel fundamental do esporte na prevenção de doenças cardiovasculares. Métodos: Este estudo conduziu testes em indicadores fisiológicos relacionados, tais como a reologia hemodinâmica em estudantes que regularmente praticam exercício físico e aqueles que não praticam exercício físico. Resultados: Estudantes que praticam exercícios regularmente e aqueles que não o fazem mobilizam uma função cardíaca mais rápida no início do treino, o que demonstra boa adaptabilidade ao esporte. Conclusão: A prescrição de exercícios de preparo físico para estudantes que se exercitam de forma completa tem o efeito mais pronunciado na função vascular. Nível de evidência Il; Estudos terapêuticos - investigação de resultados de tratamento.
\end{abstract}

Descritores: Esportes; Monitores de pressão arterial; Frequência cardíaca; Aptidão cardiorrespiratória.

\section{RESUMEN}

Introducción: El ejercicio físico puede aumentar la capacidad del cuerpo de adaptarse al medio ambientey mejorar la contractilidad del corazón. Al mismo tiempo, puede restablecer la circulación sanguínea y aumentar la capacidad pulmonaria. Objetivo: Este artículo explora el papel fundamental del deporte en la prevención de enfermedades cardiovasculares. Métodos: Este estudio condujo pruebas en indicadores fisiológicos relacionados, como la reología hemodinámica, en estudiantes que regularmente practican ejercicio físico y los que no lo practican. Resultados: Estudiantes que practican ejercicios regularmente y los que no lo hacen movilizan una función cardíaca más rápida al principio del entrenamiento, lo que demuestra buena adaptabilidad al deporte. Conclusión: La prescripción de ejercicios de preparación física para estudiantes que se ejercitan de forma completa tiene el efecto más pronunciado en la función vascular. Nivel de evidencia ll; Estudios terapéuticos - investigación de resultados de tratamiento.

Descriptores: Deportes; Monitores de presión sanguínea; Frecuencia cardiaca; Capacidad cardiovascular.

\section{INTRODUCTION}

Physical exercise has a good effect on developing various physical qualities such as strength, endurance, speed, agility, and flexibility of the human body. It can comprehensively promote the development of physical fitness.

This article takes the traditional sports majors and the management and journalism majors as the research objects. It conducts statistics, analysis, and comparative research on the physiological indicators of different groups of people after power cycling. I selected blood pressure, heart rate, and other important indicators to evaluate the cardiovascular function for experimental tests. ${ }^{1}$ The article attempts to study the impact of sports on the human body through the changes of these indicators. Through literature materials and mathematical statistics articles, explore the impact of sports on the human cardiovascular system. We hope to provide experimental data and a theoretical basis for sports in terms of fitness effects.

\section{METHODS}

\section{Research object}

There are 30 traditional sports majors and 30 management, and journalism majors included in the study. All subjects have no history of 
smoking and are in good health. Volunteers were informed of the contents of the experiment and signed a consent form before participating in the experiment. ${ }^{2}$ Students majoring in traditional national sports have undergone long-term physical training, training at least 3 times a week, and each training time is 1.5 hours. The management and journalism majors participate in physical exercises twice a week, each time for one hour. The primary conditions of the subjects are shown in Table 1.

\section{Research methods}

\section{Literature data method}

According to the research purpose of this article and the needs of the research content, we use the Internet, libraries, reference rooms, CNKI, document compilation, and other resources to collect relevant materials.

\section{Experimental method}

The experiment was carried out in two parts, with a one-week interval between the two experiments. The first experiment: The day before the subject was tested, we did not participate in any heavy physical activity or sports training and were guaranteed 8 hours of sleep. ${ }^{3}$ After a regular diet on the morning of the test day, rest for more than 1 hour. We have a heart rate at rest and perform a power bicycle load test.

The second experiment was carried out one week apart. Before the experiment, sleep, diet, and physical activity were equivalent to the first experiment. At the beginning of the second experiment, exercise on a power bicycle with a load of 50 watts for 5 minutes. Then exercise for 25 minutes at an exercise intensity of $60 \sim 70 \%$ of the maximum oxygen uptake. ${ }^{4}$ We recorded blood pressure and heart rate before exercise, immediately after exercise, 1 hour after exercise, 3 hours after exercise, and 5 hours after exercise.

\section{Cardiovascular system simulation model}

For the ventricle's cyclic diastolic and systolic movement, we usually use the pressure-volume curve to describe it visually. The pressure-volume curve relationship of the ventricle can be expressed as:

$$
p(t)=E(t)\left(V(t)-V_{d}\right)
$$

$p(t)$ represents the pressure of the ventricle. $V(t)$ represents the change in blood volume of the ventricle over time. $V_{d}$ represents the tension-free ventricular volume at the end of the ventricular systole. $E(t)$ is a time-varying elastic function. In the physiological sense, $E(t)$ represents the elastic coefficient of the myocardium. The model points out that $E(t)$ is mainly composed of two parts: the passive elasticity $E_{p}$ of the ventricle. ${ }^{5}$ It is a constant, representing the passive stretching of the myocardium when the ventricles are filled, and the value is $0.06 \mathrm{mmHg} / \mathrm{ml}$. The active elasticity of the ventricle $E_{A}(t)$ represents the active contractility of the ventricle and $E_{A}(t)$ can be obtained by the following formula:

$$
E_{A}(t)=E_{\max } \times E_{n}\left(t_{n}\right)
$$

Table 1. Basic information of subjects.

\begin{tabular}{c|c|c}
\hline Group & $\begin{array}{c}\text { National Traditional } \\
\text { Sports Major }\end{array}$ & $\begin{array}{c}\text { Management and } \\
\text { Journalism }\end{array}$ \\
\hline gender & male & male \\
\hline Sample $(\mathrm{n})$ & 30 & 30 \\
\hline Training years (years) & $6.5 \pm 3.1$ & $19.1 \pm 0.5$ \\
\hline Age (year) & $31.5 \pm 1.1$ & $66.4 \pm 9.7$ \\
\hline Weight $(\mathrm{kg})$ & $69.8 \pm 11.8$ & $175.0 \pm 7.6$ \\
\hline Height $(\mathrm{cm})$ & $173.2 \pm 6.2$ & $41.1 \pm 10.1$ \\
\hline VO2max $(\mathrm{ml} / \mathrm{min} \cdot \mathrm{kg})$ & $43.7 \pm 5.9$ & $21.8 \pm 3.7$ \\
\hline BIM & $23.2 \pm 3.3$ &
\end{tabular}

The normalization function $E_{n}\left(t_{n}\right)=1.5532 \times \frac{\left(\frac{t_{n}}{0.7}\right)^{19}}{1+\left(\frac{t_{n}}{0.7}\right)^{19}} \times \frac{1}{1+\left(\frac{t_{n}}{1.1785}\right)^{21.9}} ;$ normalizes the time $t_{n}=\frac{H R}{0.2 \times H R+4.5}$. Indicates the heart rate. $E_{\max }$ is the maximum active elasticity of the ventricle. Therefore, the myocardial elastic coefficient $E(t)$ is:

$$
E(t)=E_{A}(t)+E_{p}
$$

\section{Mathematical Statistics}

All data are expressed as plus or minus standard deviation. We use Spss13.0 statistical software for analysis and use an independent sample T-test to test the difference of sample means.

\section{RESULTS}

\section{The fitness value of sports}

Different styles, characteristics, and exercise methods of sports can develop the strength, speed, endurance, flexibility, and coordination of human muscles and affect the functions of the human cardiovascular system, respiratory system, and central nervous system. ${ }^{6}$ Therefore, vigorously developing sports plays an essential role in human health. Promoting sports and fitness activities with Chinese national characteristics has a profound impact on national fitness.

\section{The impact of sports on blood pressure and heart rate}

It can be seen from Table 2 that the systolic blood pressure of the students majoring in traditional ethnic sports is significantly higher immediately after power cycling than when they are quiet $(P=0.000)$. One hour after exercise, the systolic blood pressure returned to the resting level $(P>0.05)$. However, the systolic blood pressure of management and journalism students immediately after bicycle exercise has an inevitable increase compared with the quiet time.? Until 5 hours later, this indicator is still higher than the quiet level.

From Table 3, it can be seen that the diastolic blood pressure of the students of ethnic traditional sports majors increased significantly after 5 hours of cycling exercise compared with the quiet time $(P=0.046)$. The increase in diastolic blood pressure immediately after exercise, 1 hour and 3 hours, was not significant, and the difference was not significant. ${ }^{8}$ The diastolic blood pressure of management and journalism students increased

Table 2. Changes in systolic blood pressure after power cycling.

\begin{tabular}{c|c|c}
\hline Group & $\begin{array}{c}\text { National Traditional } \\
\text { Sports Major }\end{array}$ & $\begin{array}{c}\text { Management and } \\
\text { Journalism }\end{array}$ \\
\hline gender & male & male \\
\hline Sample $(\mathrm{n})$ & 30 & $110.0 \pm 7.7$ \\
\hline At quiet time $(\mathrm{mm} / \mathrm{Hg})$ & $115.6 \pm 9.0$ & $113.3 \pm 9.6$ \\
\hline Immediately $(\mathrm{mm} / \mathrm{Hg})$ & $134.7 \pm 18.6$ & $107.5 \pm 6.2$ \\
\hline After 1 hour $(\mathrm{mm} / \mathrm{Hg})$ & $115.3 \pm 11.2$ & $114.6 \pm 7.8$ \\
\hline After 3 hours $(\mathrm{mm} / \mathrm{Hg})$ & $113.8 \pm 11.1$ & $115.4 \pm 9.6$ \\
\hline After 5 hours $(\mathrm{mm} / \mathrm{Hg})$ & $114.7 \pm 9.8$ & \\
\hline
\end{tabular}

Table 3. Changes in diastolic blood pressure after power cycling.

\begin{tabular}{c|c|c}
\hline Group & $\begin{array}{c}\text { National Traditional } \\
\text { Sports Major }\end{array}$ & $\begin{array}{c}\text { Management and } \\
\text { Journalism }\end{array}$ \\
\hline gender & male & male \\
\hline Sample $(\mathrm{n})$ & 30 & 30 \\
\hline At quiet time $(\mathrm{mm} / \mathrm{Hg})$ & $75.3 \pm 11.1$ & $65.8 \pm 6.0$ \\
\hline Immediately $(\mathrm{mm} / \mathrm{Hg})$ & $79.1 \pm 14.1$ & $66.7 \pm 8.7$ \\
\hline After 1 hour $(\mathrm{mm} / \mathrm{Hg})$ & $78.2 \pm 7.5$ & $69.2 \pm 7.7$ \\
\hline After 3 hours $(\mathrm{mm} / \mathrm{Hg})$ & $80 \pm 7.9$ & $75.8 \pm 7.0$ \\
\hline After 5 hours $(\mathrm{mm} / \mathrm{Hg})$ & $82.4 \pm 8.7$ & $81.3 \pm 6.1$ \\
\hline
\end{tabular}


significantly after 3 hours of cycling exercise ( $P=0.001$ ) compared to rest. The increase in diastolic blood pressure immediately after exercise and 1 hour after exercise was not significant, and the difference was not significant.

From Table 4, the heart rate of the students of ethnic traditional sports majors immediately after cycling exercise is significantly higher than that at rest $(P=0.000)$. One hour after exercise, the heart rate returned to the resting level $(P>0.05)$. The heart rate of management and journalism students immediately after cycling exercise was significantly higher than at rest $(P=0.000)$. One hour after exercise $(P=0.002), 3$ hours after exercise $(P=0.003), 5$ hours after exercise $(P=0.019)$, the heart rate was still higher than the level at rest.

Table 4. Heart rate changes after power cycling.

\begin{tabular}{c|c|c}
\hline Group & $\begin{array}{c}\text { National Traditional } \\
\text { Sports Major }\end{array}$ & $\begin{array}{c}\text { Management and } \\
\text { Journalism }\end{array}$ \\
\hline gender & male & male \\
\hline Sample $(\mathrm{n})$ & 30 & 30 \\
\hline At quiet time $(\mathrm{mm} / \mathrm{Hg})$ & $77.1 \pm 6.0$ & $70.8 \pm 15.3$ \\
\hline Immediately $(\mathrm{mm} / \mathrm{Hg})$ & $169.3 \pm 7.7$ & $162.7 \pm 8.3$ \\
\hline After 1 hour $(\mathrm{mm} / \mathrm{Hg})$ & $75.5 \pm 6.8$ & $85.0 \pm 8.2$ \\
\hline After 3 hours $(\mathrm{mm} / \mathrm{Hg})$ & $72.3 \pm 7.1$ & $84.2 \pm 11.2$ \\
\hline After 5 hours $(\mathrm{mm} / \mathrm{Hg})$ & $68.4 \pm 5.0$ & $81.2 \pm 35.1$ \\
\hline
\end{tabular}

\section{DISCUSSION}

By comparing the changing trend of blood pressure after exercise, it can be found that the systolic blood pressure and pulse rate of the national traditional sports majors increase moderately after exercise, which is a normal reaction. ${ }^{9}$ The pulse of management and journalism students increased significantly after the exercise. The blood pressure was irregular, the systolic blood pressure was not raised much, and the pulse recovery time was long. This is the type of inability to respond. The faster the heart rate drops during the recovery period, and the shorter the recovery time, the better the cardiovascular function. The heart rate of the students majoring in traditional national sports has returned to the level of quiet one hour after exercise.

In contrast, the heart rate of the students majoring in management and journalism has been higher than the level of quiet time from the end of the exercise to 5 hours after exercise. The function of the cardiovascular system of the traditional national sports students after exercise is better than that of the management and journalism students. It can be inferred that long-term physical training can improve the function of the human cardiovascular system.

The systolic blood pressure of the students majoring in traditional ethnic sports after power cycling increased significantly compared with that at rest. One hour after exercise, the systolic blood pressure returned to the resting level. The systolic blood pressure of management and journalism students increased to a certain extent immediately after exercise. The systolic blood pressure was still higher than the level at rest 5 hours after exercise.

After power cycling, the diastolic blood pressure of the students majoring in traditional ethnic sports in the 5 hours after exercise was significantly higher than that in the quiet state, and the difference was not significant. ${ }^{10}$ The diastolic blood pressure of management and journalism students 3 hours after cycling exercise was significantly higher than that at rest, and the difference was not significant.

The heart rate of the students majoring in traditional national sports after power cycling increased significantly compared with that at rest. One hour after exercise, the heart rate returned to the resting level. The heart rate of management and journalism students immediately after cycling exercise was significantly higher than that of quiet time. The heart rate is still higher than the level at rest until 5 hours after exercise.

After acute exercise, the time for the systolic blood pressure and heart rate to return to a quiet level for the traditional ethnic sports students is shorter than that for the management and journalism students. Long-term physical exercise can promote the function of the human cardiovascular system.

\section{CONCLUSION}

With the vigorous development of national fitness sports in China, we should attach importance to and promote sports. Need to be committed to the development and development of sports with practical actions. The article recommends that non-physical students and people increase physical exercise appropriately. Choose suitable sports items as exercise content to enhance physical fitness. It is recommended to exercise no less than two times a week, and each exercise time is no less than 1.5 hours.

All authors declare no potential conflict of interest related to this article

\section{REFERENCES}

1. Baggish AL, Ackerman MJ, Putukian M, Lampert R. Shared Decision Making for Athletes with Cardiovascular Disease: Practical Considerations. Curr Sports Med Rep. 2019;18(3):76-81. doi: 10.1249/JSR.0000000000000575.

2. D’Ascenzi F, Caselli S, Alvino F, Digiacinto B, Lemme E, Piepoli M, et al. Cardiovascular risk profile in Olympic athletes: an unexpected and underestimated risk scenario. Br J Sports Med. 2019;53(1):37-42. doi: 10.1136/bjsports-2018-099530.

3. Baggish AL, Levine BD. Icarus and sports after COVID 19: too close to the sun? Circulation. 2020 Aug 18;142(7):615-7. doi: 10.1161/CIRCULATIONAHA.120.048335.

4. Lippi G, Henry BM, Sanchis-Gomar F. Physical inactivity and cardiovascular disease at the time of coronavirus disease 2019 (COVID-19). Eur J Prev Cardiol. 2020;27(9):906-8. doi: 10.1177/2047487320916823.

5. Rajpal S, Tong MS, Borchers J, Zareba KM, Obarski TP, Simonetti OP, et al. Cardiovascular magnetic resonance findings in competitive athletes recovering from COVID-19 infection. JAMA Cardiol. 2021;6(1):116-8. doi: 10.1001/jamacardio.2020.4916. Erratum in: JAMA Cardiol. 2021 Jan 1;6(1):123.

6. Carbone S, Kirkman DL, Garten RS, Rodriguez-Miguelez P, Artero EG, Lee DC, et al. Muscular strength and cardiovascular disease: an updated state-of-the-art narrative review. J Cardiopulm Rehabil Prev. 2020;40(5):302-9. doi: 10.1097/HCR.00000000000000525.

7. Franklin BA, Myers J, Kokkinos P. Importance of lifestyle modification on cardiovascular risk reduction: counseling strategies to maximize patient outcomes. J Cardiopulm Rehabil Prev. 2020;40(3):138-43. doi: $10.1097 /$ HCR.00000000000000496.

8. Nordengen S, Andersen LB, Solbraa AK, Riiser A. Cycling is associated with a lower incidence of cardiovascular diseases and death: Part 1 - systematic review of cohort studies with meta-analysis. Br J Sports Med. 2019;53(14):870-8. doi: 10.1136/bjsports-2018-099099.

9. Ballester R, Huertas F, Pablos-Abella C, Llorens F, Pesce C. Chronic participation in externally paced, but not self-paced sports is associated with the modulation of domain-general cognition. Eur J Sport Sci. 2019;19(8):1110-9. doi: 10.1080/17461391.2019.1580318.

10. Hansen D, Abreu A, Doherty P, Völler H. Dynamic strength training intensity in cardiovascular rehabilitation: is it time to reconsider clinical practice? A systematic review. Eur J Prev Cardiol. 2019;26(14):1483-92. doi: 10.1177/2047487319847003. 